\title{
Patterns and rates of crime evolution in Mexico
}

\author{
D. E. Santos-Reyes ${ }^{1} \&$ J. R. Santos-Reyes ${ }^{2}$ \\ ${ }^{1}$ Universidad Tecnológica de la Mixteca, \\ Km 2.5 Carretera Huajuapan-Acatlima, Huajuapan de León, Oaxaca, \\ C.P. 69000, México \\ ${ }^{2}$ Sección de Estudios de Postgrado e Investigación, \\ Escuela Superior de Ingeniería Mecánica y Eléctrica, Unidad Zacatenco, \\ IPN, Col. Lindavista, Delegación Gustavo A. Madero, D.F., C.P. 07738, \\ Mexico
}

\begin{abstract}
Mexicans are fearful and concerned about the waves of crime that have permeated the fabric of their cities and even that of small villages. In order to understand the growth of crime, institutions need to answer a key question about the rate of change of crime: How does crime evolve through time? Both academia and the public sector have paid significant attention to crime issues over the last few years. Existing approaches to crime seem to view it as an isolated event and very little attention has been given to the study of the behaviour of crime through time. This research project uses a generalised logistic model and nonlinear regression in order to develop an understanding of the dynamics of crime in Mexico. It seems that crime performance is an orderly diffusion process. The patterns of temporal diffusion of crime seem to grow slowly at the beginning, followed by an accelerating and then decelerating growth, culminating in saturation or decline. It is hoped that this sheds some light on a better understanding of the rate of crime change so that improved approaches can be formulated for preventing and controlling crime.

Keywords: crime, S-curve, diffusion, systems, non-linear regression.
\end{abstract}

\section{Introduction}

There are numerous studies, which provide evidence that Mexicans are fearful and concerned about the continuously changing rate of crime [1-3]. The increasing number of crimes of all kinds has permeated the fabric of their cities 
and even of small villages. Mexicans have witnessed, over the last few years, a significant increase in violence, especially throughout the southern, central and northern states. Not only drug-related murdering has increased, but also politicalrelated murdering, such as that of 45 indigenous people in Acteal, Chiapas (1997) and 17 in Aguas Blancas, Guerrero (1995); more recently, the uncontrolled use of the law enforcement officials to control demonstrations has violated the civil rights of ordinary citizens, and even the murdering of several members of civil organisations in Atenco and Oaxaca (2006). Despite the International Covenant on Civil rights, to which Mexico is party, it also seems that disappearances are an ongoing crime in Mexico. Over the last three decades, the use of disappearance has been an endemic practice in the army and policing. Members of opposition organisations have been the target of widespread and systematic human rights violations, including arbitrary detention, torture, disappearance, and extrajudicial execution.

Both academia and the public sector have paid significant attention to crime prevention and control issues over the last few years. Existing approaches to crime seem to view it as an isolated event and very little attention has been given to the study of the behaviour of crime as a system through time. Crime prevention and major investment in crime control depend on a correct understanding of the evolution of crime in general and of the S-shaped pattern in particular. To foster this understanding, this research project addresses the following questions: How does crime evolve? Does it follow the S-curve? Are crime changes predictable? Is the rate of crime in Mexico increasing?

The primary purpose of this research is empirical. The research questions are verified through collecting data from prevailing publications and the evolution of crime is examined, both for the entire country and for Mexico D.F. In the remaining sections of the paper, the literature review, method, preliminary results, and conclusions and further research are presented.

\section{Crime science}

Until very recently, it seems that the traditional way to approach crime, including the decision-making process, has been the trial and error. This approach has been enhanced by methods and techniques of science. Law enforcement, judicial, legislative and related institutions are working hard to dismantle long-standing barriers that separate them from scientific methods and communities. These new tools, methods and thinking constitute what is known as crime science. In essence, crime science, very much like operations research, employs scientific know-how in order to prevent and control crime [4]. Crime science embraces, among other disciplines, disciplines such as engineering design, biochemistry, material science, criminology, psychology, sociology, communications, artificial intelligence, zoology, and ecology.

\subsection{Approaching crime}

Science has been assisting institutions to innovate more creatively, to create better means, such as the development of DNA testing and evidence, 
increasingly sophisticated forms of identification, scientific evidence and expert witnesses, and advanced data collection and analysis systems. There is a growing importance of a cluster of concepts such as intelligence, knowledge, information technology, data mining, and networks [5]. Science has also been used to explain why crime situations have developed as they have over time. For example, Sirén [6] developed regression models that describe the changes in the assault rate in Finland between 1950 and 2000. Similarly, Gutauskas et al. [7] discuss the political, socio-economic, organisational and cultural issues that influence the dynamics of change in organised crime in Lithuania from the late 1980s to the early 2000s. Skogan and Hartnett [8] discuss the shape of the diffusion curve that describes the pace of adoption of information technology, and examine factors associated with the adoption and the extent to which the innovation was actually used in municipal police departments.

These developments have generated changes in the practice of policing, such as the creation and use of models of intelligence driven policing, concurrent or collaboration approaches, diffusion of information technology, problem-solving processes, crime education, and management systems.

\subsection{Approaches to crime in Mexico}

Over the last few years, there has been great interest in developing approaches to address crime in Mexico. Negrete and Zepeda [9] discusses the issues involved in improving the criminal justice system. In general it is believed that the lack of an effective control system leads to the poor performance of the Mexican justice system [10]. Also, there is a misunderstanding of the functions of the preventive police, who perform administrative functions rather than ensuring order [11]. Lack of crime investigation, making illegal profits, and abuse are common practices of policing in Mexico City [12]. In order to make policing more effective and accountable, the government should provide resources, training and education, and reduce corruption practices $[13,14]$. Buffington [15] contends that crime has followed well defined patterns since the Mexican independence era. Piccato [16] analyses the perception of crime during the last century in Mexico City. Similarly, other studies develop measures of social constructs, such as interpersonal trust, networking, membership, fear, well-being, and institutional trust [17]. Civil organisations have made significant efforts to seek justice for the increasing crime rate, in particular for the murdering of women in Cd. Juarez-El Paso [18].

\subsection{The logic of S-curves}

Engineering designers recognise that technologies evolve through an initial phase of slow growth, followed by one of fast growth, and at the final stage it flattens out $[19,20]$. When these epochs of development are plotted against time or research effort, the resulting curves tend to be S-shaped. Progress, by any measure, is normally analysed with the use of hindsight. Since the growth curve tends to be sigmoid in shape, i.e., it is not linear, thus non-linear regression analysis is used to fit the data to the growth pattern. S-curves are envelopes 
composed of smaller curves that deal with technology epochs, which themselves flatten out. And if these curves flatten out, then it seems probable that the total curve will also flatten out; i.e., it will be a component curve of some larger, and so far, unknown, technological era.

\section{Crime evolution in Mexico}

\subsection{The context}

Law enforcement institutions (the attorney general's office (PGR), the states attorney general's offices (PGJEs), and the federal district attorney general's office (PGJDF); including the ministries of public securities) are characterised by poor performance, corruption practices and high levels of impunity. The PGR, PGJEs and PGJDF are in charge of investigating crimes and prosecuting suspects, and ensuring that the legal rights and guarantees of citizens are fully respected. These institutions also have the responsibility of investigating complaints of human rights violations by law enforcement officers. However, the PGR, PGJDF and the PGJEs are subordinated to the Federal and State executives and often act in the direct interest of the current president or state governor, rather than as an independent prosecutor upholding the rule of law. These institutions have repeatedly failed to investigate crimes of all kinds and have remained subordinated to the interests of the very few who have sought to prevent access to the truth and justice.

The Mexican legal system focuses primarily on the text of actual laws than on prior court decisions. For an accused person, he/she is essentially considered guilty until proven innocent. Additionally, the role of judges is very active in developing a case and gathering evidence. Moreover, in the absence of jury trials, judges also make the ultimate decisions about the innocence or guilt of an accused person. On the other hand, the legislative system in Mexico, historically, has been very inefficient at developing new regulations and observing the behaviour of the federal and state executives.

Mexicans have carried out demonstrations throughout the country to express their concern about the increasing rate of crime, such as violence against women, kidnappings, murdering, violations of the rights of minority groups, murdering of journalists, disappearances, drug trafficking and associated violence, and the excessive use of force in the practice of policing. Over the last decades, very little attention has been given to address corruption practices, organised crime, and different manifestations of crime, which have deeply permeated the fabric of the Mexican government, political structure and daily life of the entire country.

\subsection{The method of data collection}

Although there has been a significant effort of researchers and experts for crime data gathering and analysis, a ready-made crime database does not exist for the study of crime evolution in Mexico. In this research project, crime data has been gathered, following the historical method proposed by Golder [21]. Two main 
criteria have been used to select data categories: (a) some are directly extracted from prior research, and (b) a number of crimes not addressed before. On the basis of these criteria, the following categories have been chosen: organised crime, serious state or misdemeanour and federal crime. The sample crosses a broad spectrum of crime. However, in this paper only preliminary results on serious state crime are reported.

The information required for this study is data on criminal system performance for various types of crime at different epochs of their evolution. The primary source of data are reports in technical journals, attorney generals and state offices, government publications, white papers published by $R \& D$ organisations and universities, and annual reports of NGOs. The steps for data collection of the historic method as proposed by Golder [21] have been followed closely throughout the data gathering process. A specific research question is addressed: How does crime evolve? Crime data has been gathered from different sources, such as the crime data reported by Piccato [22], crime data reported by Arango and Medina [23], crime data compiled by the PGR, and crime data published by PJGDF. The resulting data set includes information on various types of crime. It has been straightforward to establish authorship, date of publication, and to verify that the data has been the result of scientific inquiry. Moreover, Piccato, Arango and Medina, and other authors, are widely recognised experts on crime issues.

\section{Preliminary results}

First, the identification of different categories of crime and the performance attributes in each category are presented. Second, the findings on the research question regarding the shape, path, and dynamics of crime in Mexico are discussed. Nonlinear regression was used to test the existence of the S-curve.

\subsubsection{Identification of crime categories and performance attributes}

Broadly speaking, crime data categories have been classified as latent and patent crime data. In turn, these categories can be further broken down into serious crime under states jurisdiction or misdemeanour, and serious crime under federal jurisdiction. Serious crime under the federal jurisdiction includes: drug possession, alien smuggling, certain firearms/ammunition, and possession of counterfeit money. Serious state crimes include: murdering, kidnapping, rape, assault, robbery, child pornography, corruption of a minor, possession of deadly weapons and property damage. Latent crime data refers to the unregistered or unreported crimes, whilst the patent crime data refers to the registered or reported crimes. The later category has been addressed by various researchers. For the purposes of this paper, the patent crime data gathered and analysed by Piccato [22] and Arango and Medina [23] are used in order to study the dynamics of crime in Mexico.

When testing the S-shaped curves, it is recommended by Foster [20] to use performance of the system as the key independent variable. In each category, at a particular phase of crime evolution certain dimensions of performance assume 
primacy. Based on the historical description of crime, it is fairly easy to identify these dimensions. In choosing metrics of performance, output per unit of input was taken into consideration very carefully.

\subsubsection{Shape of crime evolution}

It is contended by the authors that crime evolves through $\mathrm{S}$-curves. Crime performance was plotted on the y-axis against time on the $\mathrm{x}$-axis, figure 1 . This plot suggests that crime has a slow start and a sudden fast growth. In order to verify that crime evolution follows an S-curve function, the following tests were performed.
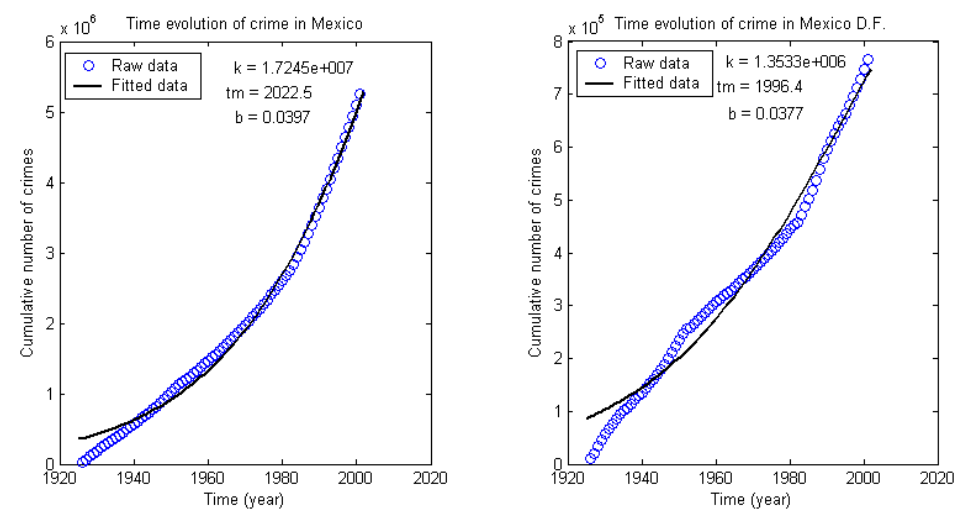

Figure 1: The diffusion of crime (misdemeanour) in Mexico and Mexico D.F.. Data Source: Piccato [22].

First, a generalised logistic function was fitted to the crime data, as reported by Piccato [22] that reveal a single S-shaped curve:

$$
Y=\frac{k}{1+e^{-b\left(t-t_{m}\right)}}
$$

where $\mathrm{Y}(\mathrm{t})$ represents the S-curve growth through time of a population or process, Y. Three parameters control the shape of the sigmoid growth trajectory: b controls the steepness (diffusion or growth rate) of the model; k denotes the asymptotic limit (or saturation level); and $t_{m}$ denotes the middle or inflection point. The nonlinear regression process in Matlab programming language was used in order to estimate the parameters of the model over the entire data sample. Second, crime data, as published by Arango and Medina [23], also seem to exhibit S-curves, figure 2. Again, the generalised logistic function was used to fit both the total crime reported for the country and to sub-sample of data reported for Mexico D.F.. The goal here is to test how well an S-curve fits on the whole sample and whether it fits better on a sub-sample than on the whole data set at the state level. 

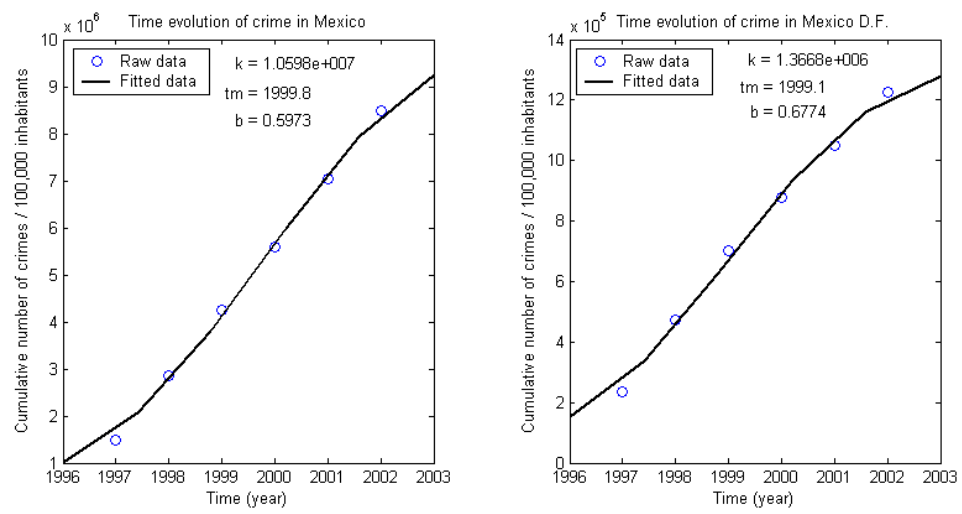

Figure 2: The diffusion of crime (misdemeanour) in Mexico, and Mexico D.F. Data Source: Arango and Medina [23].

\subsubsection{Discussion}

It seems that for the crime data set for the whole country with an apparent sigmoid curve, the generalised logistic function provides a good fit with the data set, figures 1 and 2. Also, for the crime data samples for Mexico D.F., an S-curve fits very well over the sub-samples and the entire data set, figures 1 and 2 . To summarise, the speculation of an S-shaped growth curve in crime performance in Mexico is supported for both the entire crime data set of the whole country and for the samples of data published for Mexico D.F.. The importance of these preliminary findings is that an analyst may use the generalised logistic function in order to study the dynamics of crime so that better plans for reducing and preventing crime can be visualised. Finally, from these preliminary results, it can be said that crime performance evolves through S-shaped curves. The path of crime evolution seems to be predictable, and the rate of crime change or growth increases over time.

It should be emphasised that the study described here has several limitations. First, there was a need to limit the analysis to only those published categories of crime data because of the time consuming nature and difficulty of data gathering and analysis. Second, the analysis of performance did not include the performance of the law enforcement system. Third, citizen system performance based on their behaviour with respect to crime was not incorporated in the analysis either. Finally, despite the efforts spent in the process of data collection, based on historical records, the limitation of incompleteness and reliability of data recorded by different researchers and organisations, should be emphasised.

\section{Conclusions and further research}

This paper presented the preliminary results regarding the patterns and rates of crime evolution in Mexico through the use of a generalised logistic model and the nonlinear regression process in order to fit the model to the data set. Although the results of this study are not strictly conclusive, it has several 
implications for policy-makers and decision-takers. First, using the S-curve to predict the performance of criminal systems may help to better visualise measures for reducing and preventing future crime acts. Second, the continuous emergence of new forms of crime and the steady growth of crime performance suggest that relying on the status quo is not the best approach to crime prevention and reduction. Moreover, the S-shaped time path of the evolution of technologies resembles the diffusion patterns observed in this study. These patterns of temporal diffusion have a slow growth at the beginning, followed by accelerating and then decelerating growth, culminating in saturation. Sometimes, a symmetrical decline follows or a new growth curve initiates. This means that criminal systems adapt through time. Future research includes addressing the limitations listed above, verifying the robustness of the results, and performing several analysis that cover not only patterns of temporal diffusion but also patterns of spatial diffusion.

\section{References}

[1] Shelley, Louse, Corruption and Organised Crime in Mexico in the PostPRI Transition, Journal of Contemporary Criminal Justice, Vol. 17 No. 3, August 2001 213-231.

[2] Mexico: "Disappearances": an ongoing crime. Amnesty International (AI), Library Web site. http://web.amnesty.org/library/Index/ ENGAMR410202002

[3] State of Siege: Drug-Related Violence and Corruption in Mexico, Washington Office on Latin America (WOLA), June 2006. www.wola.org/publications/publications.htm

[4] Smith, M.J. \& Tilley, N., (eds). Crime Science: New approaches to preventing and detecting crime. Willan Publishing, 2005.

[5] Brodeur, J.P. \& Dupont, B., Knowledge workers or "knowledge" workers? Policing and Society, Vol. 16, Number 1, pp. 7-26, March 2006.

[6] Sirén, R., Trends in Assault: On the relationship between the assault rate and selected social indicators in post-war Finland, Journal of Scandinavian Studies in Criminology and Crime Prevention, Vol. 3, pp. 22-49, 2002.

[7] Gutauskas, A., Juska, A., Johnstone, P. \& Pozzuto, R., Changing typology of organised crime in a post-socialist Lithuania (the late 1980s-early 200s), Global Crime, Vol. 6, No. 2, pp. 201-221, May 2004.

[8] Skogan, W.G. \& Hartnett, S.M., The diffusion of information technology in policing, Police Practice and Research, Vol. 6, No. 5, pp. 453-469, 2005.

[9] Negrete, L. \& Zepeda, G., Análisis técnico de la propuesta de reforma al sistema de justicia mexicano, Center for U.S.-Mexican Studies. (May 18, 2005). Project on Reforming the Administration of Justice in Mexico. http://repositories.cdlib.org/usmex/prajm/placencia_negrete_zepeda.

[10] Zepeda, G., La investigación de los delitos y la subversión de los principios del subsistema penal en México. (May 15, 2003). Center for 
U.S.-Mexican Studies. Project on Reforming the Administration of Justice in Mexico. http://repositories.cdlib.org/usmex/prajm/zepeda.

[11] Yanez, P., Policia preventive en la region central de México y el modelo gatadino de seguridad interior. (May 15, 2003). Center for U.S.-Mexican Studies. Project on Reforming the Administration of Justice in Mexico. http://repositories.cdlib.org/usmex/prajm/yanez.

[12] Silva, C., Abuso policial en la ciudad de México. (May 15, 2003). Center for U.S.-Mexican Studies. Project on Reforming the Administration of Justice in Mexico. http://repositories.cdlib.org/usmex/prajm/silva.

[13] Reames, B., Police forces in Mexico: a profile. (May 15 2003). Center for U.S.-Mexican Studies. Project on Reforming the Administration of Justice in Mexico. http://repositories.cdlib.org/usmex/prajm/reames.

[14] Lopez Porillo Vargas, E., Educación y entrenamiento policial para la democracia. (May 15, 2003). Center for U.S.-Mexican Studies. Project on Reforming the Administration of Justice in Mexico. http://repositories.cdlib.org/usmex/prajm/lopez_portillo.

[15] Buffington, R., Periodisation and its discontents: the social construction of crime and criminality in modern Mexico. (May 15, 2003). Center for U.S.-Mexican Studies. Project on Reforming the Administration of Justice on Mexico. http://repositories.cdlib.org/usmex/prajm/buffington.

[16] Piccato, P., A historical perspective on crime in twentieth-century Mexico City. (May 15, 2003). Center for U.S.-Mexican Studies. Project on Reforming the Administration of Justice in Mexico. http://repositories.cdlib.org/ usmex/prajm/piccato.

[17] Piccato, P., Unweaving the social fabric: the impact of crime on social capital. (May 15, 2003). Center for U.S.-Mexican Studies. Project on Reforming the Administration of Justice in Mexico. http://repositories.cdlib.org/ usmex/prajm/paras.

[18] Staudt, K. \& Coronado, I., Civic action for accountability: anti-violence organising in Cd. Juarez-el Paso. (May 15, 2003). Center for U.S.Mexican Studies. Project on Reforming the Administration of Justice in Mexico. http://repositories.cdlib.org/usmex/prajm/staudt_coronado.

[19] Rogers, E., Diffusion of innovations. First Edition. New York: The Free Press, 1962.

[20] Foster, R., Innovation: the attacker's advantage. New York: Summit Books, 1986.

[21] Golder, P.N., Historical method in marketing research with new evidence on long-term market share stability, Journal of Marketing Research, 37 (May), pp. 156-172, 2000.

[22] Piccato, P., Estadísticas del crimen en México: Series históricas, 19012001. Columbia University. On line. http://www.columbia.edu/ $\sim$ pp143/estadisticascrimen/EstadisticasSigloXX.

[23] Arango, D. \& Medina, L., Análisis y tendencia del delito en México (1997-2002). On Line. www.seguridadpublicaenmexico.org.mx/estudios $\% 20$ sobre\%20mexico/menu_2. 